\title{
Educational games: training of community healthcare agents on children's respiratory diseases*
}

\author{
Jogo educativo: capacitação de agentes comunitários de saúde sobre doenças respiratórias infantis
}

Juego educativo: capacitación de agentes comunitarios de salud sobre enfermedades respiratorias infantiles

\section{Raquel Dully Andrade ${ }^{1}$, Débora Falleiros de Mello ${ }^{2}$, Carmen Gracinda Silvan Scochi $^{3}$, Luciana Mara Monti Fonseca ${ }^{4}$}

\begin{abstract}
Objective: Evaluating the use of an educational game about children's respiratory diseases by community healthcare agents (CHAs) in the Family Health Program. Methods: This is a descriptive, intervention study, with the application of the game to 101 CHAs in Passos-MG. The game was structured with cases of children and families and their respective answer sheets. For evaluation, a test about the topic was applied before and after the intervention. Results: Correct answers in the test increased from 59.5\% to 79.3\% after participating in the game, which corresponds to a $20 \%$ increase. Conclusion: The increase in the CHA's knowledge, revealed after the intervention, indicates that the educational game is a satisfactory instrument for healthcare education.
\end{abstract}

Keywords: Respiratory tract diseases; Health education; Community health aides/education; Child

\section{RESUMO}

Objetivo: Avaliar a utilização de um jogo educativo sobre doenças respiratórias infantis por agentes comunitários de saúde (ACS) de Programa de Saúde da Família. Métodos: Trata-se de estudo descritivo e de intervenção, com a aplicação do jogo em 101 ACS de Passos-MG. O jogo foi estruturado em forma de casos de crianças e famílias e suas respectivas cartelas de respostas. Para avaliação, foi aplicado um teste sobre o tema, antes e após a intervenção. Resultados: As respostas corretas no teste passaram de 59,5\% para 79,3\%, após terem participado do jogo, perfazendo um aumento de cerca de $20 \%$. Conclusão: A elevação no conhecimento dos ACS, revelada após a intervenção, aponta o jogo educativo como instrumento satisfatório na educação em saúde.

Descritores: Doenças respiratórias; Educação em saúde; Auxiliares de saúde comunitária/educação; Criança

\section{RESUMEN}

Objetivo: Evaluar la utilización de un juego educativo, sobre enfermedades respiratorias infantiles, por agentes comunitarios de salud (ACS) del Programa de Salud de la Familia. Métodos: Se trata de un estudio descriptivo y de una intervención, con la aplicación del juego en 101 ACS de Passos-MG. El juego fue estructurado en forma de casos de niños y familias y sus respectivas tarjetas de respuestas. Para la evaluación, fue aplicado un test sobre el tema, antes y después de la intervención. Resultados: Las respuestas correctas en el test pasaron de 59,5\% a $79,3 \%$, después de haber participado en el juego, logrando un aumento de aproximadamente el 20\%. Conclusión: La elevación en conocimiento de los ACS, revelada después de la intervención, señala al juego educativo como un instrumento satisfactorio en la educación en salud.

Descriptores: Enfermedades respiratorias; Educación en salud; Auxiliares de salud comunitaria/educación; Niño

\footnotetext{
* Project developed in the city of Passos-MG, as part of the Master's Thesis of Raquel Dully Andrade for the Public Health Nursing Graduate Program at EERP - USP, supported by the Brazilian Council of Scientific and Technological Development (CNPq).

${ }^{1}$ M.Sc., Professor at the Nursing Faculty of Fundação de Ensino Superior de Passos - FESP - Passos (MG), Brazil.

${ }_{2}$ Associate Professor at the Maternal-Infant and Public Health Nursing Department of Escola de Enfermagem de Ribeirão Preto, Universidade de São Paulo - USP - Ribeirão Preto, (SP), Brazil.

${ }^{3}$ Full Professor at the Maternal-Infant and Public Health Nursing Department of of Escola de Enfermagem de Ribeirão Preto, Universidade de São Paulo - USP - Ribeirão Preto, Brazil. - Ribeirão Preto, (SP), Brazil.

${ }^{4}$ RN, Ph.D., at Escola de Enfermagem de Ribeirão Preto, Universidade de São Paulo - USP - Ribeirão Preto, (SP), Brazil.
} 


\section{INTRODUCTION}

Child mortality rates have been falling in Brazil. In the 1994-2004 period, there was a 32.6\% decrease, with an estimated number of 26.6 deaths per thousand liveborns for 2004, the most recent research year ${ }^{(1)}$. Respiratory diseases hold the first place among the causes of death in children from 1 to 4 years old, being responsible for about $50 \%$ of the causes of hospital admission in this age range, and for $30 \%$ to $50 \%$ of the children cared for in emergency services and healthcare centers ${ }^{(2)}$.

Low body weight at birth, malnutrition, lacking or short period of breastfeeding and immunization deficiency rank among the risk factors of great importance, associated to higher frequencies and gravity of acute respiratory infection (ARI) episodes in children under 5 years old.

Allied to epidemiological aspects, political guidelines are elaborated to create healthcare models. Therefore, also seeking to attain the general health goals proposed by the World Health Organization, the Community Healthcare Agent Program (PACS) was created in Brazil in the early 1990s, whose central goal was to extend the coverage of the public healthcare system to rural and urban periphery populations, prioritizing the maternal-infant population and offering healthcare actions focused especially on preventive practices ${ }^{(4)}$. In this proposal, the community healthcare agent appeared as a new healthcare worker, being an important social actor in primary healthcare practices. This worker has a complex activity and plays the role of mediator ${ }^{(5)}$.

The 1990s brought to the healthcare sector a revaluation of the Family theme, peaking with the creation of the Family Healthcare Program (FHP) in 1994, with the proposal of rekindling primary healthcare, centered on the family and community dimensions ${ }^{(6)}$. The FHP is an important strategy in the promotion of children's health, with a relevant optimization of the respective human resources, highlighting the space occupied by the community healthcare agents who have been keeping close contact with the children's mothers and families. In the permanent education of these healthcare workers, the educational game can become a satisfactory innovation in several aspects.

Games are considered interactive and motivational resources in healthcare education, capable of generating learning, promoting dialogue, facilitating the approach of themes and the debate of everyday situations ${ }^{(7-8)}$. When seen through the participants' perspective, the educational game is considered fun, stimulating, a clarifier of doubts, facilitator of learning, interactive, innovative and illustrative $e^{(9)}$. The use of educational games is highlighted in these aspects and capable of contributing to the construction of healthcare knowledge in accordance with the FHP's characteristics, objectives and goals.

\section{OBJECTIVE}

This study aimed to evaluate the utilization of an educational game about children's respiratory diseases by community healthcare agents working for the FHP in Passos - MG, Brazil.

\section{METHODS}

This is a descriptive intervention study about the evaluation of the application of a game in the healthcare education of community healthcare agents (CHA) from family healthcare teams, developed in Passos, a city in the Southeast of Minas Gerais. It is part of the Master's thesis entitled "Development and utilization of educational games about the prevention of respiratory diseases in children under 5 years old for the training of community healthcare agents" (10).

The intervention was the application of the game, considered as an introduced factor, whose effects were evaluated by pre-testing (before the intervention) and post-testing (after the intervention). The test, applied to the CHAs before and after playing the educational game, contains 22 questions $^{(10)}$ about children's respiratory diseases.

Regarding the study universe, the game and the preand post-testing instrument were applied by the researcher in the CHA population of the 17 FHP teams in the city of Passos - MG, with six CHAs in each group, totaling 102 agents. One of the agents refused to participate. Thus, the study population was composed by 101 participants.

The 17 teams were identified by the 17 first letters of the alphabet (A, B, C, D, E, F, G, H, I, J, K, L, M, N, O, $\mathrm{P}, \mathrm{Q})$. Since each FHP team has six CHAs, and considering that a number of 12 participants was satisfactory for the game dynamics, it was played in groups of two teams, reaching 12 players per game. In order to apply the educational dynamics with the 17 teams in the city, eight meetings were held with groups of two teams each, with one of the teams playing the game in a ninth meeting, due to the odd number of FHP teams in the city.

The distribution of the groups where the educational game process was developed is as follows, with its respective teams of FHP participants, according to the alphabetic classification described above: Group 1: teams A and B, Group 2: teams C and D, Group 3: teams E and F, Group 4: teams G and H, Group 5: teams I and J, Group 6: teams $\mathrm{K}$ and L, Group 7: teams $\mathrm{M}$ and $\mathrm{N}$, Group 8: teams O and P, Group 9: team Q.

Therefore, the number of participants in each game group varied from six to twelve.

In order to be applicable in CHA training, the 
elaboration of this educational game about children's respiratory diseases was based on the recommendations of the Ministry of Health(11), the $\mathrm{WHO}^{(12)}$, some authors $^{(3,13-14)}$, orientations directed to the leaders of Pastoral da Criança (Children's Pastoral) ${ }^{(15)}$, as well as on the researchers' experience. After the elaboration, the game was evaluated by two specialists in the theme with FHP experience (a physician and a nurse).

This game was structured as 18 distinct cases and their respective answers ${ }^{(10)}$, to be discussed in three game rounds. Concepts and definitions about children's respiratory diseases, as well as basic care for their prevention, treatment and recovery were presented in the cases, aiming to expose the reality found by the community agents in the healthcare provided to children and their families. In the three rounds, three colors were used for the cards (red, blue and green), one for each round.

The game board was structured as a pathway divided in 36 spaces, with a start and an end point for the players. To represent each player on the game board (for a group of six participants - one team) or each of the six pairs of players (for a group of twelve participants - two teams), six game pawns were used. The amount of spaces to advance on the board corresponded to the number obtained at the roll of a dice. The 18 cards of the game, corresponding to the number of cases, were elaborated with colored envelopes. A question was present on the outer part of the envelope and, inside the envelope, there was a card with the answer about the correct action for that case, which would only be exposed after the players discussed and answered the question based on their own knowledge.

The educational dynamic was planned to be done in three rounds of six sequential cards each (18 cases and their respective cases altogether), so that each participant or pair would draw a card containing a case, read it aloud to the group and answer it, firstly based on his or her knowledge and experiences. If the answer provided by the participant was correct, the player who answered the question correctly rolled the dice, and the resulting number was the amount of spaces the player would move his pawn forward on the game board. In case the answer was correct but incomplete, the participation of all players was encouraged, so that they could complete or clarify the answer, but, in this case, the player who started the answer is the one who cast the dice. If the answer was incorrect, the mediator asked the group if anyone knew the correct answer, and whoever answered it correctly would throw the dice and move his or her pawn forward on the game board. If nobody answered the question correctly, the mediator started building the answer with the participation of the players, using participative dynamics. In this case, nobody advanced his/her pawn on the board. If no pawn reached the endpoint by the end of the game, the winner was the participant or the pair whose pawn was closest to the last space on the board.

The authors chose to group two teams located at the shortest possible distance from one another, trying to facilitate the movement of one of the teams to the other's FHP unit, where the game would be applied. Altogether, nine educational meetings were held.

A test with 22 questions ${ }^{(10)}$ about children's respiratory diseases was given to the CHAs participating in the educational activity before and immediately after the development of the game dynamics. Later, these tests were graded, by identifying and comparing the amount of questions with the correct answers, before and after the educational intervention, aiming to evaluate the described application of the game.

In pre- and post-testing, the following concepts were defined as the criteria for classification of knowledge: insufficient (up to $24 \%$ correct answers), regular (25\% to $49 \%$ correct answers), good (50\% to $74 \%$ correct answers) and excellent (75\% to $100 \%$ correct answers). This classification was based on the concepts and respective amount of correct answers, converted in percentages here, used in another study about the utilization of educational games in breastfeeding and newborn care ${ }^{(16)}$.

The research was approved by the Research Ethics Committee at the University of São Paulo at Ribeirão Preto College of Nursing. The CHAs were informed about the study goals and procedures. Those who agreed to participate signed a term of consent.

\section{RESULTS}

Evaluation of the use of an educational game about children's respiratory diseases by community healthcare agents

The study describes the correct answers in the test, before and after the game, in the groups of community healthcare agent teams, as seen in Table 1.

In each of the nine meetings held, the CHA groups had a good performance (50\% to $74 \%$ correct answers) in the pre-game period, and eight of them had excellent performances ( $75 \%$ to $100 \%$ correct answers) in the postgame period.

Table 2 shows the classification of knowledge about children's respiratory diseases of the 101 community healthcare agents, before and after participating in the game.

It can be verified that, in the test taken before the application of the educational game about children's respiratory diseases, $17(16.8 \%)$ community healthcare agents had a regular evaluation (25\% to $49 \%$ correct answers); 78 of the CHAs (77.2\%) had good knowledge (50\% to $74 \%$ correct answers) and only $6(6.0 \%)$ of these 
healthcare workers had knowledge rated as excellent $(75 \%$ to $100 \%$ correct answers).

Table 1 - average number of correct answers, before and after the game, in the test about respiratory diseases in children, in each group of community healthcare agent teams.

\begin{tabular}{lccc}
\hline CHA Group & \multirow{2}{*}{ FHP Teams } & \multicolumn{2}{c}{ Average number of correct answers (\%) } \\
\cline { 3 - 4 } & & Pre-game & Post-game \\
\hline 1 & A and B & 56.1 & 81.1 \\
2 & C and D & 59.5 & 73.5 \\
3 & E and F & 56.8 & 79.5 \\
4 & G and H & 54.9 & 79.9 \\
5 & I and J & 58.3 & 78.0 \\
6 & K and L & 58.7 & 76.9 \\
7 & M and N & 60.6 & 77.3 \\
8 & $\mathrm{O}$ and P & 59.9 & 77.3 \\
9 & Q & 70.5 & 90.2 \\
\hline Total & $\mathbf{1 7}$ & $\mathbf{5 9 . 5}$ & $\mathbf{7 9 . 3}$ \\
\hline
\end{tabular}

Table 2 - Classification of the community healthcare agents' knowledge before and after the game.

\begin{tabular}{lrrrr}
\hline \multirow{2}{*}{ Knowledge } & \multicolumn{3}{c}{ Pre-game } & \multicolumn{2}{c}{ Post-game } \\
\cline { 2 - 5 } & no. & $\%$ & no. & \% \\
\hline Insufficient & - & - & - & - \\
Regular & 17 & 16.8 & - & - \\
Good & 78 & 77.2 & 33 & 32.7 \\
Excellent & 6 & 6.0 & 68 & 67.3 \\
\hline Total & 101 & 100.0 & 101 & 100.0 \\
\hline
\end{tabular}

In the post-game period, $68(67.3 \%)$ community healthcare agents showed excellent knowledge, 33 $(32.7 \%)$ were rated as good, and no participant was rated as regular.

The classification of knowledge shown by the community healthcare agents shifted from the concept good $(77.2 \%)$ before the game dynamics and in the concept excellent $(67.3 \%)$ after it was finished.

Besides, the incidence of knowledge rated as regular was considerable before the game $(16.8 \%)$, and decreased to zero after the participation of the community healthcare agents in the educational activity.

The utilization of an educational game was effective in the teaching-learning process, reflecting in a $61.4 \%$ increase in the percentage of community healthcare agents with knowledge rated as excellent.

\section{DISCUSSION}

The increased levels of knowledge through educational games were also found in a study applying pre-tests and post-tests, mediated by a game about breastfeeding and newborn care, obtaining a 61.1\% increase in the incidence of puerperae with knowledge rated as excellent ${ }^{(16)}$.

The elaboration of the educational game contents, dynamics and material about children's respiratory diseases, as well as its application to the 17 family healthcare team CHAs, promoted the interweaving between technical knowledge provided by the educational material and the empirical knowledge revealed by the players.

The characteristics involved in the group education process through the application of the game allow for the expression of words and gestures, establishing interactions among the participants, triggering mechanisms of cooperation among the game partners ${ }^{(9)}$ and, therefore, making it possible to develop communicative and teamwork skills, so important in the healthcare service context, particularly in the work of community healthcare agents with the families ${ }^{(5)}$.

Discussions about everyday situations in the healthcare area could be enriched with the use of educational games, easing the understanding of specific themes, awakening curiosities, promoting dialogue, interaction and motivation to learn ${ }^{(7-8)}$.

The process of evaluation is considered a fundamental stage within the pedagogical proposals, by using several tools. The evaluation is focused in completing and supporting the construction of knowledge, in order to follow and correct the pedagogical work, reorienting planning and encouraging learning ${ }^{(17)}$. The use of pre- and post-tests portrays the evaluation in the scenario of the appropriation of contents, and has a diagnostic function, which may be done before and after the pedagogical action.

Since the application of group dynamics started with the opinions and knowledge of the community healthcare agents about the topic, it assumes that the educator will valuate these subjects' previous knowledge, as well as highlight issues about bonds and welcoming in their work with the families ${ }^{(18)}$.

The increased knowledge of the community healthcare agents, revealed in the pre- and post-educational intervention tests, appoints that the process of knowledge construction through the application of educational games to community healthcare agents showed that this instrument is effective and satisfactory. It meets the requirements of healthcare education related to the current healthcare service context, especially those of the Family Healthcare Strategy, with the important presence of the community healthcare agent included here.

\section{CONCLUSION}

The number of correct answers increased, meaning that most community healthcare agents had their knowledge rated as good in the pre-game test and excellent in the post-game test.

It should also be highlighted that the incidence of knowledge rated as regular was present in the test applied 
before the educational intervention, and became null after its development.

The nurse plays an important role in healthcare team supervision, being responsible for developing permanent educational activities among the healthcare workers. This professional should have the creativity and humanization of work relations in mind when expanding the work instruments. The goal is to mitigate the pressures common in the healthcare scenario, thus contributing to the extension of these aspects to the healthcare provided to

\section{REFERENCES}

1. Fundo das Nações Unidas para a Infância (UNICEF). Situação da infância brasileira 2006. Crianças de até 6 anos: o direito à sobrevivência e ao desenvolvimento. [Internet] Brasília (DF): UNICEF; c2006. [citado 2006 Jul 9]. Disponível em: www.unicef.org/brazil/pt/Pags_001_007_Abre.pdf

2. Veríssimo MDLOR, Sigaud CHS. Assistência de enfermagem à criança com agravos respiratórios. In: Brasil. Instituto para o Desenvolvimento da Saúde. Universidade de São Paulo. Ministério da Saúde. Manual de Enfermagem. São Paulo: Instituto para o Desenvolvimento da Saúde; 2001. p. 95-8.

3. Benguigui Y. Investigações operacionais sobre o controle das infecções respiratórias agudas (IRA). Washington: OPAS/OMS; 1997.227 p.

4. Rodrigues CRF. Participação e atenção primária em saúde: o Programa de Saúde da Família em Camaragibe-PE (19941997) [dissertação]. São Paulo: Faculdade de Saúde Publica da Universidade de São Paulo; 1998.

5. Lunardelo SR, Mello DF, Palha PF, Pinto IC, Zilbermann CR. Comunicación en el equipo de salud de la familia y el trabajo del agente comunitario de salud. Enferm Comun [Internet]. 2007 [cited 2007 Nov 19]; 3(1). Available from: http://www.index-f.com/comunitaria/v3n1/ec3457r.php

6. Vasconcelos EM. A priorização da família nas políticas de saúde. Saúde Debate. 1999; 23(53): 6-19.

7. Rebello S, Monteiro S, Vargas EP. A visão de escolares sobre drogas no uso de um jogo educativo. Interface Comun Saude Educ. 2001; 5(8):75-88.

8. Schall VT, Monteiro S, Rebello SM, Torres M. Evaluation of the ZIG-ZAIDS - game: an entertaining educational tool for HIV/Aids prevention. Cad Saude Publica = Rep Public Health. 1999; 15(Supl 2): 107-19.

9. Santos MG, Magalhães TS, Bittencourt P. Playing and learning - Bate-boca, an educational game concerning schistosomiasis, AIDS, dengue and leishmaniasis. Cienc Cult (Sao Paulo). 1993; 45(6): 381-5.

10. Andrade RD. Desenvolvimento e utilização de jogo educativo services users, moving away from the crystallized practices of the team members and favoring the same behavior in the relations between the team and the clientele.

It is important to address questions about the insertion of ludic methodological processes in healthcare education in further depth, with a view to expanding their use, improving the characteristics of their dynamics and explorating knowledge about a possible impact of their results on the expansion and qualitative improvement of current healthcare practices.

sobre a prevenção de doenças respiratórias no seguimento de crianças menores de cinco anos para a capacitação de agentes comunitários de saúde [dissertação]. Ribeirão Preto: Escola de Enfermagem de Ribeirão Preto da Universidade de São Paulo; 2004.

11. Brasil. Ministério da Saúde. Secretaria de Políticas de Saúde. Departamento de Atenção Básica. Saúde da Criança: acompanhamento do crescimento e desenvolvimento infantil. Brasília: Ministério da Saúde; 2002. (Série: Cadernos de Atenção Básica n.11, Série: A. Normas e manuais técnicos n.173).

12. Organização Mundial da Saúde (OMS). Conversando com as mães sobre AIDPI. Traduzido por: Maria Helena Valente e Maria de La Ó Ramallo Veríssimo. São Paulo: Ministério da Saúde/Brasil; 1999.

13. Benguigui Y. Acute respiratory infections control in the context of the IMCI strategy in the Americas. Rev Bras Saude Matern Infant. 2003; 3(1): 25-36.

14. Benício MHD’A, Cardoso MRA, Gouveia NC, Monteiro CA. Tendência secular da doença respiratória na infância na cidade de São Paulo (1984-1996). Rev Saude Publica = J Public Health. 2000; 34(6 Supl): 91-101.

15. Guia do líder da Pastoral da Criança. Curitiba: MS; 2000.255 p.

16. Fonseca LMM, Scochi CGS, Mello DF. Educação em saúde de puérperas em alojamento conjunto neonatal: aquisição de conhecimento mediado pelo uso de um jogo educativo. Rev Latinoam Enferm. 2002; 10(2): 166-71.

17. Brasil. Ministério da Saúde. Proposta pedagógica: avaliando a ação. Brasília: Ministério da Saúde; Rio de Janeiro: Ministério da Saúde: Fundação Oswaldo Cruz, Escola Nacional de Saúde Pública; 2000. (Série: Formação pedagógica em educação profissional na área de saúde: enfermagem; módulo 8).

18. Schimith MD, Lima MADS. Acolhimento e vínculo em uma equipe do Programa Saúde da Família. Cad Saude Publica = Rep Public Health. 2004; 20(6): 1487-94. 